\title{
PEMANFAATAN LUMPUR LAPINDO SEBAGAI BAHAN BAKU PEMBUATAN AMPLAS
}

\author{
Novita Listiyani ${ }^{1 \star}$, Anggi Putra Dharmawan ${ }^{1}$, Fifi Afifah ${ }^{1}$, Sari Edi \\ Cahyaningrum 1 .
}

${ }^{1}$ Jurusan Kimia, Universitas Negeri Surabaya, Jalan Ketintang, Surabaya, 60231

* Author Utama, email: novitalistiyani@mhs.unesa.ac.id

Co-author 1, email: anggidharmawan@mhs.unesa.ac.id

Co-author 2, email: : fifiafifah16030234013@mhs.unesa.ac.id

Co-author 3, email sariedicahyaningrum@unesa.ac.id

\begin{abstract}
Research on efficient dust lapindo as raw material for making sandpaper has been done. The purpose of this research is to know the number of silica, type, and method of making of lapindo to make sandpaper from Lapindo mud, sample preparation, extraction using $\mathrm{HCl} 6 \mathrm{M}$, analysis using XRD and FTIR, and making of sandpaper. The results of this study indicate that the result of silica extraction using $\mathrm{HCl} 6 \mathrm{M}$ has a permitted silica content in the presence of a very strong functional group, which will have a strong appeal as well.
\end{abstract}

Keywords: Lapindo mud, Silica, and Sandpaper.

\section{ABSTRAK}

Penelitian tentang pemanfaatan lumpur lapindo sebagai bahan baku pembuatan amplas telah dilakukan. Tujuan dari penelitian ini adalah mengetahui jumlah silika, karakteristik, dan metode pembuatan amplas dari lumpur lapindo Untuk membuat amplas dari lumpur lapindo, dilakukan preparasi sampel, ektraksi menggunakan $\mathrm{HCl} 6 \mathrm{M}$, menganalisis menggunakan XRD dan FTIR, serta pembuatan amplasnya. Hasil penelitian ini menunjukkan bahwa hasil ektraksi silika menggunakan $\mathrm{HCl} 6 \mathrm{M}$ memiliki kandungan silika yang ditunjukkan dengan adanya gugus fungsi Si dengan $O$ yang sangat kuat, sehingga amplas yang dibuat akan memiliki daya tarik yang kuat juga.

Kata Kunci: Lumpur lapindo, Silika, dan Amplas.

\section{PENDAHULUAN}

PT Lapindo Brantas adalah perusahaan minyak yang diduga oleh banyak pihak sebagai pihak yang harus bertanggung jawab atas terjadinya semburan lumpur panas yang terjadi di Porong, Sidoarjo [2]. Lumpur lapindo ini mengeluarkan semburan lumpur panas yang banyak sehingga area lumpur lapindo semakin meluas. Semakin luasnya area semburan lumpur dan semakin besarnya semburan lumpur perharinya menimbulkan banyak kerugian bagi warga sekitarnya.
Lumpur lapindo tidak hanya menimbulkan kerugian, tetapi memiliki potensi yang besar yaitu sebagai bahan bangunan karena kandungan silika dan alumina yang terkadung hampir $50 \%$ dari lumpur lapindo membuat salah satu lumpur panas ini dapat digunakan sebagai salah satu bahan bangunan sebagai pengganti semen; keramik; genteng; batu bata; dan batako.

Telah dilakukan penelitian tentang lumpur Sidoarjo, kandungan senyawa yang terdapat dalam lumpur Sidoarjo adalah $\mathrm{Al}_{2} \mathrm{O}_{3}$ $16 \%, \mathrm{SiO}_{2} 49,9 \%, \mathrm{~K}_{2} \mathrm{O} 2,51 \%, \mathrm{CaO} 6,14 \%$, $\mathrm{TiO}_{2} \quad 1,74 \%$, dan $\mathrm{Fe}_{2} \mathrm{O}_{3} \quad 21,7 \%$ [5]. 
Berdasarkan jumlah kandungan senyawa $\mathrm{SiO}_{2}$ tersebut, maka lumpur lapindo diharapkan bisa dimanfaatkan sebagai bahan baku pembuatan amplas. Amplas ini akan dibuat dengan bahan baku lumpur lapindo yang mengandung senyawa $\mathrm{SiO} 2$ atau silika dengan penambahan minyak cat dan minyak pernis sebagai perekatnya yang diaplikasikan pada kertas anti air yang tebal. Pada penelitian ini difokuskan pada pemanfaatan dari lumpur lapindo sebagai bahan baku pembuatan amplas kering.

\section{METODE PENELITIAN}

\section{Material}

Lumpur lapindo, Aquades, $\mathrm{HCl}$ pekat proanalis $37 \%$, minyak pernis, minyak cat, dan kertas anti air.

\section{Instrumentasi}

Ayakan ukuran 80 mesh, ayakan ukuran 120 mesh, ayakan ukuran 325 mesh, alu, botol semprot, cawan petri, corong buchner, corong kaca, Fourier Transform Infra Red (FTIR) merk Shimadzu IR Prestige 21, AIM8800 , gelas ukur merck $10 \mathrm{~mL}$, gelas kimia merck $100 \mathrm{~mL}$, indikator universal, kaca arloji, kertas saring, labu ukur merck $100 \mathrm{~mL}$, magnet, magnetic stirrer, mortal, neraca analitik, oven, pipet tetes, pipet volume, propipet, spatula, dan XRD.

\section{Prosedur}

\section{Ekstraksi Silika}

Lumpur lapindo yang diperoleh dari daerah lumpur lapindo Sidoarjo. Ekstraksi silika yang ada dalam lumpur lapindo dilakukan menggunakan larutan $\mathrm{HCl}$. Pada tahap preparasi sampel, lumpur lapindo diambil secukupnya, lalu direndam menggunakan larutan $\mathrm{HCl} 2 \mathrm{M}$ selama 12 jam, lalu disaring menggunakan corong buchner, lalu dicuci menggunakan aquades, dan endapan yang didapatkan dikeringkan pada suhu $100-110{ }^{\circ} \mathrm{C}$ sampai sampel kering.

Sampel kering yang didapatkan, lalu diambil sebanyak 10 gram, lalu dimasukkan ke gelas kimia $100 \mathrm{~mL}$, lalu ditambahkan 30 $\mathrm{mL}$ larutan $\mathrm{HCl} 6 \mathrm{M}$, lalu di strirer selama 2 jam pada suhu $90{ }^{\circ} \mathrm{C}$, lalu disaring menggunakan corong buchen, lalu dicuci menggunakan aquades, dan didapatkan endapan silika $\left(\mathrm{SiO}_{2}\right)$ kemudian dikeringkan pada oven pada suhu $100-110{ }^{\circ} \mathrm{C}$ sampai kering.

\section{Uji Ekstrak SIlika}

Ekstrak silika diuji dengan XRD secara kualitatif dan kuantitatif untuk mengetahui fasa kristal yang terbentuk. Ekstrak silika diuji dengan FTIR secara kualitatif dan kuantitatif untuk mengetahui adanya gugus fungsi serta jumlah gugus fungsinya.

\section{Pembuatan Amplas}

Ekstrak silika dihaluskan menggunakan mortal alu, lalu diayak menggunakan ukuran ayakan yang berbeda, maka didapatkan bubuk halus ekstrak silika dengan ukuran butiran yang berbeda. Minyak cat sebanyak $100 \mathrm{~mL}$ dimasukkan ke dalam gelas kimia, lalu ditambahkan minyak pernis sebanyak $100 \mathrm{~mL}$, lalu diaduk sampai homogen, Ialu disapukan secara merata ke atas kertas anti air dengan menggunakan kuas, lalu ditaburkan secara merata bubuk halus ekstrak silika, lalu dikeringkan dibawah sinar 
matahari selama 2 hari, maka didapatkan amplas kering.

\section{HASIL DAN PEMBAHASAN}

\section{Uji XRD}

Hasil uji Difraksi Sinar-X terhadap sampel ektstrak silika yang telah diekstrak menggunakan larutan $\mathrm{HCl}$ yang diuji di Laboratorium Divisi Karakterisasi Material Jurusan Teknik Material dan Metalurgi FTIITS pada tanggal 26 juni 2018 adalah seperti pada Gambar 1. Uji difraksi sinar X dilakukan pada sudut pendek $\left(5-60^{\circ}\right)$ dimaksudkan sebagai uji awal untuk identifikasi keberadaan atau kandungan bahan oksida yang diharapkan yaitu $\mathrm{SiO}_{2}$ sebagai bahan dasar untuk penelitian selanjutnya.

Data sifraksi sinar-x dari ekstrak silika seperti yang tampak pada Gambar 1, kemudian dihaluskan dengan cara manual dengan mortal alu dan disaring, baru kemudian diuji menggunakan XRD. Tampak dari hasil uji difraksi sinar-x ini (sudut (20): 560) menunjukkan bahwa bidang kristal (peak) lebih didominasi oleh fasa illite dan quartz. Quartz merupakan salah satu fasa kristal dari $\mathrm{SiO}_{2}$ selain trymite dan crystobalite. Intensitas $100 \%$ berada pada posisi $2 \theta=$ $29,52^{0}$ dan teridentifikasi sebagai fasa quartz seperti yang terlihat pada Gambar 1 .

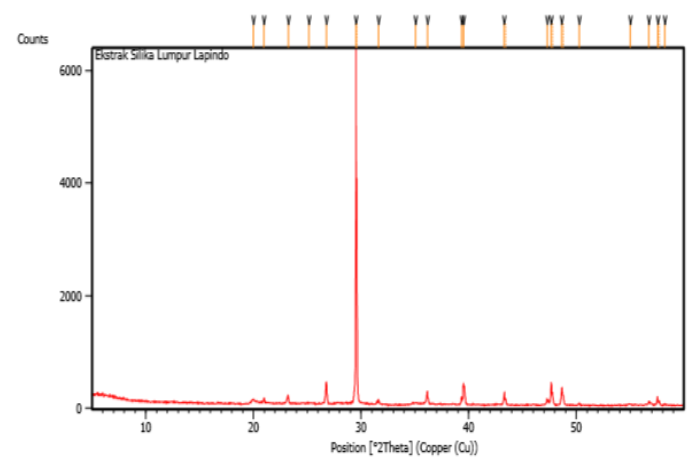

Gambar 1. Derajat Kristanilitas $\mathrm{SiO}_{2}$ Hasil Ekstrasi.

Hal tersebut dikarenakan pada kondisi asam puncak difraksi cenderung ke arah $2 \theta$ yang lebih besar, sedangkan pada kondisi basa cenderung ke arah yang lebih kecil. Selain itu, pada kondisi asam fasa quartz juga bertambah dan fasa illite berkurang yang berarti bahwa ekstrak silika yang didapatkan masih berada pada kondisi asam.

\section{Uji FTIR}

Hasil uji FTIR terhadap sampel ektstrak silika yang telah diekstrak menggunakan larutan $\mathrm{HCl}$ yang diuji di Laboratorium Divisi Karakterisasi Material Jurusan Teknik Material dan Metalurgi FTI-ITS pada tanggal 26 juni 2018 adalah seperti pada Gambar 2. Pola serapan vibrasi gelombang yang terbentuk dianalisis untuk mengetahui dengan jelas gugus fungsi yang telah terbentuk dari sampel yang telah diuji. Tampak hasil uji sampel pada Gambar 2.

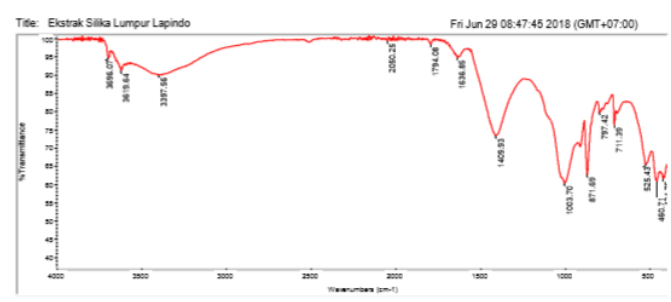

Gambar 2. Spektra FTIR $\mathrm{SiO}_{2}$ Hasil Ekstrasi. 
Posisi puncak serapan bilangan gelombang $465-475 \mathrm{~cm}^{-1}, 795-875 \mathrm{~cm}^{-1}$, dan $3000-4000 \mathrm{~cm}^{-1}$ menunjukkan pola serapan dari gugus fungsi $\mathrm{Si}-\mathrm{O}$, gugus $\mathrm{OH}$ dari $\mathrm{SiO}$, dan gugus $\mathrm{O}-\mathrm{H}$ [3]. Hal ini menunjukkan bahwa ekstrak silika mempunyai kandungan silika yang ditunjukkan dengan adanya gugus fungsi $\mathrm{Si}-\mathrm{O}$, gugus $\mathrm{OH}$ dari $\mathrm{SiO}$, dan gugus $\mathrm{O}-\mathrm{H}$.

\section{Pembuatan Amplas}

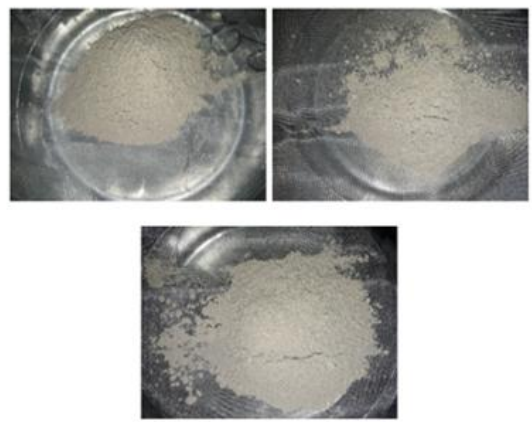

Gambar 3. $\mathrm{SiO}_{2}$ Hasil Ekstraksi yang Disaring.

Ekstrak silika yang telah diekstrak, kemudian dihaluskan menggunakan mortal alu, lalu diayak dengan mesh yang berbeda yaitu 80; 120; dan 325 mesh, maka didapatkan bubuk halus ekstrak silika dengan ukuran butiran yang berbeda. Minyak cat sebanyak $100 \mathrm{~mL}$ dimasukkan ke dalam gelas kimia, lalu ditambahkan minyak pernis sebanyak $100 \mathrm{~mL}$, lalu diaduk sampai homogen, lalu disapukan secara merata ke atas kertas anti air dengan menggunakan kuas, lalu ditaburkan secara merata bubuk halus ekstrak silika, lalu dikeringkan dibawah sinar matahari selama 2 hari, maka didapatkan amplas kering.
Berdasarkan kegiatan penelitian yang telah dilakukan, telah didapatkan luaran berupa paten dan pendaftaran artikel ilmiah sehingga secara keseluruhan kemajuan pelaksanaan penelitian yang sudah mencapai $90 \%$.

\section{KESIMPULAN}

Dilakukan penelitian tentang pembuatan amplas berbahan baku silika dari lumpur lapindo sidoarjo. Ektraksi silika ini diektraksi dengan larutan $\mathrm{HCl} 6 \mathrm{M}$. Pada penelitian ini ektraksi silika meggunakan larutan $\mathrm{HCl} 6 \mathrm{M}$ akan diuji menggunakan XRD dan FTIR. Hasil uji XRD menunjukkan bahwa bidang kristal (peak) lebih didominasi oleh fasa quartz berada pada posisi $2 \theta=29,52^{\circ}$. Hasil uji FTIR posisi puncak serapan bilangan gelombang $465-475 \mathrm{~cm}^{-1}, 795-875 \mathrm{~cm}^{-1}$, dan 3000-4000 $\mathrm{cm}^{-1}$ menunjukkan pola serapan dari gugus fungsi $\mathrm{Si}-\mathrm{O}$, gugus $\mathrm{OH}$ dari $\mathrm{SiO}$, dan gugus $\mathrm{O}-\mathrm{H}$ yang berarti terdapat kandungan silika pada ekstrak silika tersebut. Ekstrak silika akan digunakan sebagai bahan baku pembuatan amplas. Hasil penelitian ini sudah dipatenkan ke Dirjen HAKI.

\section{DAFTAR PUSTAKA}

[1] Munasir, Ahmad Mirwan Abdullah, Triwikantoro. Sintesis Silika Amorf dari Bahan Alam Lumpur Sidoarjo dengan Metode Kopresipitasi. Prosiding Seminar Nasional UNNES. Semarang: Universitas Negeri Semarang. 2010

[2] Mungkono dan Triwulan. Bahan Bangunan dari Lumpur Lapindo Aman Bagi Kesehatan. Surabaya: ITS. 2006.

[3] A. P.K. Jal, M. Sudarshan, A. Saha, Sabita Patel, B.K. Mishra. Synthesis and characterization of nanosilica prepared by precipitation method. England: Aspects. 2004

[4] Rawtani, A.V. \& Rao, M.S. "Syntesis of ZSM-5 Zeolite Using Silica from Rice Husk Ash". India Engineering Chemistry Resources, 28: 1411-1414. 1989.

[5] Rosmawati, A. Studi Prosedur Preparasi Gel pada Sintesis Aerogel Silika dari Lumpur Sidoarjo. Skripsi. Malang: FMIPA Universitas Brawijaya. 2012. 